\title{
'I Don’t Belong Anymore’: Undocumented Latino Immigrants Encounter Social Services in the United States
}

\begin{abstract}
This paper investigates the identity shifts undocumented Latino immigrants in Boston experience in their transitioning into adulthood. In order to better understand how Latino immigrants adapt to the host society, we analyze the interactions between Latino immigrants and social services, represented by their providers, to see how these interactions affect their ethnic identity.

This article offers an original and unique perspective on identity from the perspective of the relations between social service providers and recipients of these services. The aim is to expand the current knowledge on the incorporation of immigrants through the multiple acculturation effects that are generated in relations with social services.

The article is based on semi-structured interviews with undocumented Latino immigrants who grew up in the United States. The results show that, as they transition into adulthood, undocumented Latinos face new obstacles which force them to strengthen their ethnic identity in order to remain a part of American society.
\end{abstract}

Key words: Undocumented; immigrants; Latino(a)(s); social services; incorporation 
An estimated 11.5 million undocumented immigrants reside in the United States. Most undocumented immigrants are Latinos, and many arrive to the country at a young age. It is estimated that there are 1.3 million undocumented children (under the age of 18), and 1.6 million youth between the ages of 18 and 24 currently living in the United States (Hoefer, Rytina \& Baker, 2011). Undocumented immigrants, who represent 28 percent of all foreignborn individuals in the United States (Passel \& Cohn 2011), are barred from most social benefits in the country (Kullgren, 2003; Siddiqi, Zuberi \& Nguyen, 2009), and do not qualify for public financial aid for higher education (Erisman \& Looney, 2007). Fear of deportation and the stigma associated with being undocumented prevent most undocumented Latinos from accessing adequate housing, food, or health care (Abrego \& Gonzales 2010; Dang Giordano \& Kim, 2012; Larchanché, 2012).

Although the growth of the undocumented population in the United States generated an increased interest for understanding the mechanisms of assimilation of this population (Gleeson \& Gonzales 2012), the role of social services remains understudied. Research largely neglected this this aspect of incorporation partly because few social benefits are available to the undocumented in the United States. Yet, most undocumented immigrants interact with providers of social services through the school system, religious organizations, government offices, and voluntary associations.

Several theories of immigrant assimilation exist. Two of the main models of assimilation in American society present opposing trajectories: while some populations gradually assimilate through successive generations and eventually display a diminished salience of ethnic identity, as exemplified by European immigrants, other minority groups experience persistent segregation and discrimination, as has been the case for African Americans (Sears, Fu, Henry \& Bui, 2003). The literature traditionally analyses incorporation by examining the 
socioeconomic status of immigrants through the lens of income, occupation and educational attainment as proxies for socioeconomic mobility (Massey, Durand \& Malone, 2003; Rumbaut, 2008; Gans, 1992). Research on incorporation from the perspective of identity (Massey \& Sánchez, 2010), or on how undocumented immigrants’ interactions with social services contribute to the formation of their ethnic identity and their subsequent assimilation, is less frequent.

The main goal of this study is to explore how interactions with social services affect the ethnic identity of undocumented Latino immigrants who grew up in the United States. We sought to examine how the transition into adulthood, and the consequent loss of protection from social services, impacted the identity formation and the feelings of belonging to America, of undocumented Latino immigrants.

Undocumented immigrants, ethnic identity formation, and the role of social services.

Undocumented children come rapidly into contact with educational institutions in the United States. The 1982 Supreme Court decision in Plyer vs. Doe, declared that depriving undocumented children of an education was unconstitutional, and allowed undocumented children to benefit from the same K-12 educational opportunities than are available to children authorized to live on US soil, including free meals and special education services. Additionally, under the Family Educational Rights and Privacy Act (1974), schools are not allowed to report undocumented students to authorities. However, at the age of 18, these undocumented children leave the shelter of this protective legal environment and lose access to the social services which they were once granted.

Ethnic identity is an indicator of immigrants' assimilation, or the adoption of level of adoption of the host society's culture and their degree of retention of their own culture (Phinney, 
Horencyk, Liebkind \& Vedder, 2001). The concept of identity can encompass various types of identities, such as cultural, racial or ethnic (Brubaker \& Cooper, 2000; Schwartz, Montgomery \& Briones, 2006). While there is not one universal definition of ethnic identity, the term is considered to be part of the broader concept of cultural identity (Phinney, Horencyk, Liebkind \& Vedder, 2001), and is often analyzed with the associated term national identity. Although ethnic identity and national identity are considered to measure independent constructs, they can be used as indicators of assimilation. Ethnic identity plays a particularly important role during adolescence and the transitioning into adulthood as immigrants become increasingly aware of their differences with the majority group and explore their identities options (Waters, 1990; Quintana, Vogel \& Ybarra, 1991; Marcia, 2002).

Studies have shown that ethnic identity evolves with time (Tovar \& Feliciano, 2009; Phinney \& Ong, 2007) and in response to social and political contexts (Sabatier, 2008; Tovar \& Feliciano, 2009). Although immigrant youth tend to Americanize relatively quickly (Stepick \& Stepick, 2002) and adopt many aspects of American cultures and values (Waters, 1990), they seem to retain part of their ethnic identity (Stepick \& Stepick, 2002). Research has highlighted the dual role of ethnic identity, which "seems to operate both to buffer and exacerbate the negative effects of discrimination across a variety of ethnic groups spanning adolescence to late adulthood” (Yip, Gee \& Takeuchi, 2008).

As undocumented Latinos transition into adulthood, they also transition into illegality and move from a somewhat protected status under which they had access to education and other social benefits, to the more vulnerable category of 'undocumented adults' who must learn how to navigate a new system (Ellis \& Chen, 2013). The passage to adulthood leave these undocumented children uncertain of their own identity and sense of belonging, as they lose the legal protection they were granted as children (Suárez-Orozco, Bang \& Kim, 2011). 
Undocumented children are schooled in the Unites States to perceive themselves as their documented peers. However, as soon as they leave this cocoon of belonging that is the school setting, undocumented adults quickly learn that they are not like the rest of Americans (Gleeson \& Gonzales, 2012). While many have the same career expectations and ambition as their documented peers, as they transition to adulthood, undocumented Latinos lose access to the mechanisms that promote social mobility (Pérez, 2012). Undocumented immigrants face limitations to find employment, to get a driver's license, and to enrol in higher education (Abrego, 2006; Abrego, 2008). They are can no longer live like their documented peers, for whom nothing has changed and who are rightfully allowed to pursue their ambition and goals. They must embrace their illegal status by readjusting their aspirations, changing their social circles, and learning new skills in order to survive (Gonzales, 2011). Adulthood, for undocumented Latinos, represents a radical change in which they learn how to live 'in the shadows'. This change is often accompanied by feelings of being an outsider in a hostile environment (Suarez-Orozco et al. 2011).

Transitioning into adulthood also becomes a turning point in the life of undocumented Latinos because they must face new systemic barriers to provide for themselves and their families (Gonzales, Suarez-Orozco \& Dedios-Sanguineti, 2013). Undocumented immigrants are at greater risk of poverty than other immigrants (Passel 2009; Passel \& Cohn, 2011), further increasing their need to resort to social services to meet basic needs. However, their transition to "illegality" is accompanied by a re-categorization of their deservingness. Undocumented adults are barred from most social benefits, which promotes social stratification (Cebulko, 2014) and leaves their opportunities to access mechanisms of social mobility (i.e. health, education, housing, nutrition) to the discretion of bureaucrats and providers of services. This very same discretion is based on discourses of deservingness, which, in the collective 
imaginary, most undocumented Latinos do not possess (Sargent 2012; Viladrich 2012). Public opinion and the media increasingly portray undocumented Latinos in the United States as criminals and law-breakers, and thus, undeserving of the protection of the State (Waters \& Pineau, 2015).

Prior studies have shown that Latinos’ experiences with social services have an impact on their sense of belonging and identity formation. For some, benefiting from services reinforces feelings of belonging, while for others see it as a failure and opt for what Philip Warin calls 'non take-up’ (Warin, 2007). We extend previous scholarship and explore how undocumented immigrants’ transition to illegality and the subsequent re-identification as outsiders underserving of the protection of the state influenced their feelings of belonging to America.

\section{Method}

The data for the study derives from 32 semi-structured qualitative interviews of Latino immigrants that were conducted in Boston in 2012. Grounded theory was used to uncover the mechanisms at work in the identity formation and assimilation of undocumented Latino youth through social services. Although there is a growing body of literature related to

undocumented immigrants and undocumented youth in the United States, our approach was to put aside existing theories and remain as open as possible in order not to stir the interviewee's responses in any particular direction. The interview guide was designed to collect standardized information as well as to allow the respondents to comment and provide their own subjective opinion about each of the questions. When new questions emerged from interviews, they were added to the interview guide and were asked in the next interviews.

\section{Recruitment process}


The Institutional Review Board of Harvard University approved the project and the recruitment process began. It involved purposeful selection in order to achieve a high degree of socioeconomic variety and participants were selected to maximize diversity. The researchers relied initially on exploratory ethnography in the selected neighborhoods. Then, numerous points of entry were utilized for recruiting respondents. The researchers gained entry into the Latino communities in Boston by joining in various celebrations and festivals, by taking part in religious services and by offering services to the community. Further, taking part in neighborhood meetings in the various neighborhoods led to a selection process that yielded a great diversity of respondents. Boston was chosen because the city has experienced important Latino immigration during the last decades. As of 2010, Latinos accounted for 19.9\% of the total population of Boston, with 143,455 individuals; close to half of these residents are foreign-born. The recruitment process was repeated at numerous sites in Boston: particularly in East Boston, Jamaica Plain and Roxbury. The respondents were given an informed consent form to read and keep, explaining the scope and the purpose of the project. Once the initial interviews were completed, the snowball method was applied in order to diversify the original sample and to increase the sample size. The data collection method made it possible to obtain a sample stratified by country of origin (most Spanish-speaking countries of North, Central and South America, as well as the Caribbean countries are represented), by migratory status (the respondents are either currently undocumented immigrants and had been at some point) and by age, which ranges from 18 until 35. Their first language is Spanish, and 95\% of the interviews were conducted in that language. The respondents received $\$ 25$ grocery vouchers in financial compensation for their participation in the interviews.

\section{Data Collection}


We contacted the Latino community with a recruitment flyer about the purpose of the study. The flyer was posted in Spanish and in English in social service agencies, neighbourhood associations, churches, clinics, hospitals, and schools. In addition, we attended several events in the Latino communities. Through repeated attendance at these events we recruited a first cohort of participants, who subsequently assisted with the recruitment of more participants. To protect participants, we did not collect personal identifying information and we obtained respondents' verbal consent prior to the interviews. Although immigrants could choose to be informed and interviewed in English or Spanish, the vast majority preferred Spanish. Audiotaped interviews took place at service locations, public parks, consulates, churches, immigrant associations, and immigrant houses.

\section{Interview format}

The semi-structured interviews and biographical interviews, lasting between 40 and 90 minutes and averaging about 50 minutes each, made possible a systematic harvesting of data relating to the respondents' socioeconomic profile. In each case, permission for recording the conversation was obtained from the interviewees. The interviews permitted in-depth discussion of a series of predetermined subjects. In addition, an exploratory approach gave the respondents the opportunity to comment on their use of social services, and their perceived assimilation into American society. This format was employed in order to steer the interview, while still leaving latitude for responses and topics that the interviewee wished to explore, and thus to offer opportunities for in-depth exploration of new paths that opened up in the course of the conversation. In this way, the researchers were able to collect data that gave them a better grasp of the respondents' subjective views concerning their assimilation in the receiving society as affected by experiences with social services. Through this format, the researchers harvested data that reflected the respondents' subjective understanding of their assimilation in the receiving society through the variety of their experiences. The data was 
then coded using a qualitative data analysis software, Atlas.ti. Each interview was coded using categories based on the interview guide. A second round of coding allowed to code the more subjective information related to the respondent's opinions. The researchers subsequently transcribed the interviews in complete anonymity for those surveyed, by changing their first names and erasing their last names. All respondents received a hand-out in Spanish describing the project and informing them how their responses would be used. After having transcribed the interviews, they were coded with the Atlas.ti qualitative analysis program. The first round of coding, based on pre-existing codes derived from the interview guide, processed the socioeconomic and demographic information of the interviewees. A second round of coding then made it possible to explore the collected data in a more analytical manner, by creating a database from a thematic re-reading of the interviews.

\section{Data Analysis}

Interviews were transcribed into Spanish (or English when the interview was in English) and translated into English. They were then analyzed using Atlas.ti. Two main rounds of coding we conducted: first, the interviews were coded based on the initial interview guide. This first round encoded the main socioeconomic characteristics of the respondents, their immigration status and the story behind it, their current living conditions in the United States, the types of assistance and the information they have received about these programs and whether their experiences with each of the services were negative or positive. Then, a second round of coding was conducted to codify information which was not initially present in the initial codebook but emerged from the first round of coding. Thus, the subjective understanding of the respondents was uncovered by coding information related for instance to their relations with other Latino groups, in particular those working as social service providers. 


\section{Findings}

This study puts forth the process relative to the identity shifts experienced by undocumented Latino youth who grew up in the US as they transition to adulthood. At the age of 18, these undocumented children leave the shelter of this protective legal environment and lose access to the social services which they were once granted. This paper puts forward three sets of findings relating to the impact of loss of access to social services on the identity formation and subsequent assimilation of undocumented Latino youth in the city of Boston.

1- Alienation from American society and loss ‘American identity’.

First, this study evidences that some undocumented youth Latinos become gradually alienated from American society, as they learn of the limitations imposed by their migratory status and face new forms of discrimination. Analysis of the interviews shows that the undocumented Latino youth interviewed, when trying to access social services, are now confronted to a new type of discrimination based on their migratory status. During their childhood and adolescence, they may have experienced discrimination due to their ethnicity but they were relatively protected from discrimination based on their migratory status. However, when they become adults, they are no longer sheltered and are suddenly directly confronted with discrimination based on their immigration status. They indicate that the behavior and attitudes of some social service providers is sometimes hostile when these workers become aware of their client's immigration status. This attitude reinforces these Latino youth's feeling of alienation toward American society.

This is evidenced by Juan, a young Salvadorian who came to the United States undocumented, as he explains that some social service providers adopt a different attitude upon learning of the migratory status of an undocumented individual. The perceived 
discrimination that Juan experienced when seeking help seems to have led him to distance himself from American society and reinforce his Salvadorian identity.

“(...) I have seen hospitals when you tell them that you are undocumented they change the conversation style. (...) They start asking some questions that I am pretty sure they don't need [the answer to] (...) A few things that happened with people undocumented [sic], you usually get like, you got to do whatever they say (...) what I saw in the places that you go looking for help, [the service providers say:] 'we are the people who give you help so you are going to do what we say', 'we are above, you are low, you want something, do what I say' (...) It makes you feel like the poor immigrant who came here from a third world country."

During the interview, Juan commented that he "[doesn’t] belong anymore”; he now more rarely spends time with his American friends, and prefers to be with fellow Salvadorians who are in a similar migratory situation. Juan decided to isolate themselves from American society by refusing to use the social services he may be entitled to. He explains that he feels uncomfortable asking for help or going to the hospital because of the treatment he has sometimes received due to his migratory status:

“In my case that's why I don't go to those places because you are always crossing your fingers that you will find a person that is going to be a human person that you can have a conversation with, not someone who by just seeing you is going to start asking you things".

This attitude may in part be an attempt to avoid being reminded of what he considers his 'inferior' status or avoid future similar scenarios based on his status. 
As the needs of these young adults evolve, they become increasingly aware of the limitations linked to their migratory status and of the negative stereotype associated with being undocumented. This becomes especially clear when they attempt to obtain social services and face social workers who refuse to help them or provide inaccurate information. These negative experiences lead these undocumented Latino youths to question their sense of belonging to American society and separate themselves from an environment which became hostile. For instance, Ana, an undocumented single mother who was born in the Dominican Republic and arrived in the United States as a teenager, explains that now that she is an adult, she is no longer untitled to the few benefits that she received as a child. She describes her adult life as a constant fight and no longer feels that she belongs to American society. She contrasts her experience as an undocumented adult to the experiences of her children. When she attempted to receive food stamps for her newborn daughter, the social worker who took her case falsely told her that not only was she not eligible, but that applying for financial aid would get her deported.

“(...) the girl [social worker] (...) even threatened me with immigration, (...) she said by telephone: 'you have to forget about this case because you told us in the application [that you were undocumented]...' I didn't say that I was undocumented, illegal, I was just saying that my children had social security, I am not lying, and I have the copy, I filled it, because they give you a copy (...). Then she said: 'but you know the illegals do not qualify”. I know the illegals do not qualify here, absolutely, but I am eligible because of the children. (...) My kids get it [medical insurance] but they told me that it isn't through me, it is only because they are under 18, and I am their guardian, you know? (...) Now I am no longer eligible, I don't belong anymore, now I have to fight a lot, I have to defend myself, I won't chicken 
out, and I have to fight. If they [the social service providers] are mean to me and ask for a lot of things, I do it, I give it to them, you know?”

Misinformation provided by social workers, abuse of power and discrimination may thus further alienate undocumented Latino youth from American society. Among the interviewees, the vast majority uses words such a 'fight', defend myself', 'battle' to describe what their life is like as undocumented youth. The negative context of reception that these undocumented Latino youths receive from social service providers when they become adult makes them fully aware of their ostracized status.

2- Navigating between ethnic and American identities

Analysis of the interviews also brings to light the impact that the context of reception has on their sense of belonging of the undocumented Latino youth. From the interviews, it emerged that these youths are often thought not to be able to speak English due to their ethnic background but also their inability to provide proper documentation. This reinforces the disconnect between self-identity and the identity that others associate with them: on one hand, studies have shown that their language ability is often comparable to that of American citizens (e.g. Street et al. 2013), and on the other hand, the double exclusion that they sometimes seem to experience due to their ethnic background and their migratory status excludes them from the country they grew up in and the society with which they associate. For instance, Yohanna, who arrived to the United States at the age of fourteen from the Dominican Republic, used to assist nurses at a local clinic. She recalls experiencing discrimination from her manager, who eventually fired her, for allegedly not being able to speak English to her customers. Raised in the United States throughout her adolescence, Yohanna speaks English fluently and therefore felt that her manager's attitude was unjustified. 
"We had this staff lounge and we used to chat in the back and sometimes she [the manager] heard me talking in Spanish with the co-workers (...) and one day she says to me, I will always remember. It was a Saturday and I was working seven to three and she says to me 'Yohanna can you do me a favour? Can you check this person's blood sugar?' (...) So the person declined, and they have the right to decline the treatment (...). So the guy said, 'I am sorry' he was an elderly person, he said 'I don't want you to take my blood, I want my nurse to do it, because you are a new person here and I don't trust you'. I said, ok, that's fine you have the right. So, I went to her and I told what he said and you know what she says to me? [She makes an aside remark to the interviewer: "What language are you and I talking? We are talking English and you can understand me perfectly right?] And she was like 'he probably didn't understand what you said because you speak another language'. She said that, I mean, I said to her, I spoke to the guy in English I did not talk to him in Spanish ok? And all the nurses, all the white nurses they looked like, what is wrong with this person why is she talking to her like that? So, I just got really, really, depressed and I started to cry".

In order to buffer the negative consequences of perceived feeling of discrimination and to compensate the loss of access to social services, these undocumented Latino youth sometimes learn to re-embrace their immigrant identity. A finding that emerged from analyzing the interviews was that part of doing so entails navigating between different social circles. Such immigrants go back and forth between the network of peers formed of American citizens (for example peers met at school) and the network of undocumented immigrants (for example relatives, and providers of illegal services). Social capital thus seems to play a key role for 
these undocumented youth, who appear to develop different types of networks to overcome the difficulties linked to their migratory status. Parallels can be drawn here between the findings on this study and the work of Gonzales (2011) who analyzed the 'transition into illegality’ of undocumented immigrants.

We use here the term of 'immigrantization', to describe the phenomenon of appropriating an immigrant identity. As shown by our interviews, this occurs in part because immigrant networks are often better apt at providing the know-how facilitating access to some social services. These networks may also provide the resources that undocumented immigrants may need to circumvent the limitations imposed by their migratory status and therefore compensate for the loss of access to social services accessible to legal immigrants and citizens. Thus, paradoxically, undocumented Latino youth seem to rely on ethnic networks in order to maintain their assimilation into society, and therefore retain, at least partially, their American identity. Their perception of self-identity and their attitudes is modified, as they go back and forth between the sense of belonging into American society and the feeling of being excluded from it. They sometimes reinforce their ethnic ties in order to obtain a sense of belonging to a group. For instance, Silvia, an undocumented Dominican immigrant, turned to members of the Latino community in order to circumvent the limitations of her status. Since she cannot receive unemployment benefits and has not been able to find a job because of she is undocumented, she was advised by other members of the Latino community to maximize the help she can receive. She does so by lying about her marital situation to social services to receive more gas and electricity assistance:

"I was working in a bakery but one day they fired all the illegals, sand they fired me. I was making decent money there, I was working 40 hours a week and was making $\$ 300$ a week. (...) I told myself we wouldn't be able to make ends meet even if he [her partner] worked more, so I said I'm going 
to lie. Just like a Puerto Rican girl told me to do in the park, she asked me if I got assistance and when I explained, she told me: 'If you tell the truth here, they will not help you; here, if you lie, you'll get more assistance, and if you tell the truth, you will never get assistance,' that's what she said. They know the tricks."

When asked whether she received similar help or advice from her American friends, Silvia explained that she does not mention those subjects with them. This further stresses the unique role of each network:

“With my American friends, we don't talk about that [how to obtain more assistance]. It's not the same with them. We are more different now. (...) I feel more Dominican now.”

Some of these undocumented youth who find themselves unable to obtain employment or assistance via the legal path when they become adults tap into their ethnic network in order to find employment in or help from their ethnic community. Doing so may reactivate their sense of belonging to their ethnic community. It may further distance them from American society, which is represented by the social service providers who they fear will turn them down. A barrier between 'us', the ingroup, and 'them', the out-group, is erected, and these undocumented Latino youths seem to progressively learn to navigate between their native and ethnic identities in order to bypass the obstacles that are now part of their daily lives.

3- Amienation from the Latino community 
Going back and forth between these different networks seems to be translated into the adoption of varied identities on the part of these young undocumented Latinos, particularly the re-appropriation of their ethnic identity. However, analysis of the interviews shows that the Latino community itself sometimes proves to be estranging to these undocumented youths. They seem to experience a double form of alienation from the U.S. population in general, as well as from their own community. The respondents stated that they experience more discrimination from service providers that are themselves Latinos than they do from Anglo or African American service providers. This was well illustrated by Gladys, who arrived as a teenager from the Dominican Republic with a tourist visa. She explains that the misinformation and discrimination that undocumented Latinos experience regarding their eligibility to certain social programs has to do with their undocumented status.

\section{"Often they [Latino service providers] can probably do it [help people by providing assistance], they say that ah no ... that they won't even give them that, because they don't have papers, because there are many people in this situation. (...) There is discrimination among us Latinos."}

Most of the respondents who perceived discrimination from documented Latinos, complained that often these social workers deliberately try to put some distance between themselves and their undocumented customers. Some of the factors that may prompt documented Latino service providers to discriminate against undocumented Latino may be the stigma that is sometimes associated with undocumented immigrants. It seems that some 'legal' Latino service providers try to deny the shared connection with undocumented Latinos in order to dissociate themselves from a group that they perceive as prejudicial to their ambitions. The refusal to associate with undocumented immigrants sometimes take the form of discriminatory acts towards those undocumented immigrants. These negative experiences lead some undocumented Latino youth to question their own ethnic identity. According to Maria 
Patricia, an undocumented young immigrant from Colombia who arrived as a child to the United States, people in her situation feel that they do not belong anywhere.

“I don’t really feel Colombian, but I am not American either, you know. I can't even get a job here! I look different, so people know that I am not from here. I think I can cook Colombian food but that's it, you know? Sometimes people from my own country, they feel that they are better than me. If you tell them you don't have papers, they don't want to talk to you anymore. They won't help you. They make you feel that you don't belong”.

The perceived feelings of discrimination from documented Latino service providers lead some undocumented Latino youth to dissociate with their own ethnic group. These youths often feel progressively alienated from American society as well as part of their ethnic communities, notably from documented Latinos. Therefore, it seems that these youths progressively assimilate into the small section of undocumented Latino immigrants, thereby reinforcing their seclusion from American society.

\section{Conclusions}

Our study explored how transitioning into adulthood and the consequent loss of protection from social services, impacted the identity formation and the feelings of belonging to America of undocumented Latino youth that grew up in the US. This paper bridges a gap in the literature by showing how the identity of these undocumented youth shifts with time, as they learn to adapt to the restriction of being undocumented adults, vacillating between their identification with the country in which they grew up and the identity bestowed upon them by immigration services and the society at large. 
This paper evidences a paradox: in order for these youth to cling onto their American identity, which they refuse to relinquish, they are forced to learn to become immigrants and adopt some of the techniques which they hope will help them assimilate or maintain their assimilation into American society.

With adulthood comes a new form of exclusion based on migratory status and symbolized by the perceived prejudicial treatment experienced by undocumented Latino youth. Experiences of discrimination tend to alienate these young adults from a society in which they have developed a sense of belonging, thus creating ambiguity for the development of their identity. They have to learn to 'regress' and become immigrants like their parents, even though they grew up in the United States, and, paradoxically, use ethnic networks in order to maintain their assimilation into American society. They begin to distance themselves from American society, in order to find alternative solutions to the limitations of their status.

However, attempts at using their ethnic background to seek help are sometimes hampered as these undocumented Latino youths also face discrimination perpetrated by fellow co-ethnics: in their interactions with social services, for instance, they unexpectedly seem to receive better service from non-Latino Whites in comparison with fellow Latino social workers. Indeed, Latino social service providers are more mindful of the social stigma associated with undocumented immigrants, and therefore refuse to provide help in an effort to distance themselves from these 'undeserving Latinos', thereby replicating some of the behaviors of the dominant group by creating boundaries between whom they consider at the top of the hierarchy and those at the bottom

This form of secondary marginalization represents one of the multiple barriers and obstacles which undocumented Latino youth must overcome in order to remain a part of American society. The liminality of their status forces them to readjust and regularly swift their identities back and forth between their ethnic and American identities. 


\section{Declaration of Conflicting Interests}

The author(s) declared no potential conflicts of interest with respect to the research,

authorship, and/or publication of this article.

\section{Funding}

The author(s) disclosed receipt of the following financial support for the research, authorship, and/or publication of this article: This work was supported by a grant to XXX?

\section{Biographies of authors:}

\section{References:}

Abrego, L. (2008). Legitimacy, Social Identity, and the Mobilization of Law: The Effects of Assembly Bill 540 on Undocumented Students in California. Law \& Social Inquiry, 33(3), 709-734. http://doi.org/10.1111/j.1747-4469.2008.00119.x

Abrego, L., \& Gonzales, R. (2010). Blocked Paths, Uncertain Futures: The Postsecondary Education and Labor Market Prospects of Undocumented Latino Youth. Journal of Education for Students Placed at Risk (JESPAR), 15(1-2), 144-157. http://doi.org/10.1080/10824661003635168

Abrego, L. (2006). “I Can’T Go to College Because I Don’T Have Papers”: Incorporation Patterns Of Latino Undocumented Youth. Latino Studies, 4(3), 212-231. http://doi.org/10.1057/palgrave.lst.8600200

Brubaker, R., \& Cooper, F. (2000). Beyond “identity.” Theory and Society, 29(1), 1-47. http://doi.org/10.1023/A:1007068714468

Cebulko, K. (2014). Documented, Undocumented, and Liminally Legal: Legal Status During the Transition to Adulthood for 1.5-Generation Brazilian Immigrants. The Sociological Quarterly, 55(1), 143-167. http://doi.org/10.1111/tsq.12045

Dang, B. N., Giordano, T. P., \& Kim, J. H. (2011). Sociocultural and Structural Barriers to Care Among Undocumented Latino Immigrants with HIV Infection. Journal of Immigrant and Minority Health, 14(1), 124-131. http://doi.org/10.1007/s10903-0119542-X

Ellis, L. M., \& Chen, E. C. (2013). Negotiating identity development among undocumented immigrant college students: a grounded theory study. Journal of Counseling Psychology, 60(2), 251-264. http://doi.org/10.1037/a0031350

Erikson, E. H. (Erik H. (1968). Identity, youth, and crisis (1st ed.). New York: WWNorton. 
Erisman, W., \& Looney, S. (2007). Opening the Door to the American Dream: Increasing Higher Education Access and Success for Immigrants. Institute for Higher Education Policy. Retrieved from http://eric.ed.gov/?id=ED497030

Feliciano, C. (2009). Not Mexican-American, but Mexican: Shifting ethnic self-identifications among children of Mexican immigrants. Latino Studies, 7(2), 197-221.

Gans, H. J. (1992). Second-generation decline: Scenarios for the economic and ethnic futures of the post-1965 American immigrants. Ethnic and Racial Studies, 15(2), 173-192. http://doi.org/10.1080/01419870.1992.9993740

Gleeson, S., \& Gonzales, R. G. (2012). When Do Papers Matter? An Institutional Analysis of Undocumented Life in the United States. International Migration, 50(4), 1-19. http://doi.org/10.1111/j.1468-2435.2011.00726.x

Gonzales, R. G. (2011). Learning to Be Illegal: Undocumented Youth and Shifting Legal Contexts in the Transition to Adulthood. American Sociological Review, 76(4), 602619. http://doi.org/10.1177/0003122411411901

Gonzales, R. G., Suárez-Orozco, C., \& Dedios-Sanguineti, M. C. (2013). No Place to Belong: Contextualizing Concepts of Mental Health Among Undocumented Immigrant Youth in the United States. American Behavioral Scientist, 2764213487349. http://doi.org/10.1177/0002764213487349

Phinney, J S. (2001). Ethnic Identity, Immigration, and Well-Being: An Interactional Perspective. Journal of Social Issues, 57 (3), 493 - 510 (2001), 57(3).

Furstenberg, F. F., \& Rumbaut, R. G. (2008). On the Frontier of Adulthood: Theory, Research, and Public Policy. University of Chicago Press.

Kullgren, J. T. (2003). Restrictions on Undocumented Immigrants' Access to Health Services: The Public Health Implications of Welfare Reform. American Journal of Public Health, 93(10), 1630-1633.

Larchanché, S. (2012). Intangible obstacles: Health implications of stigmatization, structural violence, and fear among undocumented immigrants in France. Social Science \& Medicine, 74(6), 858-863. http://doi.org/10.1016/j.socscimed.2011.08.016

Marcia, J. E. (2002). Identity and Psychosocial Development in Adulthood. Identity, 2(1), 728. http://doi.org/10.1207/S1532706XID0201_02

Massey, D. S., Durand, J., \& Malone, N. J. (2003). Beyond Smoke and Mirrors: Mexican Immigration in an Era of Economic Integration. Russell Sage Foundation.

Massey, D. S., \& Sánchez, M. (2010). Brokered Boundaries: Immigrant Identity in AntiImmigrant Times. Russell Sage Foundation.

Ortega, A. N., Fang, H., Perez, V. H., Rizzo, J. A., Carter - Pokras, O., Wallace, S. P., \& Gelberg, L. (2007). Health care access, use of services, and experiences among undocumented Mexicans and other Latinos.(Report). Archives of Internal Medicine, 167(21), 2354.

Pérez, W. (2012). Americans by heart: undocumented Latino students and the promise of higher education. New York: Teachers College Press.

Phinney, J. S., \& Ong, A. D. (2007). Conceptualization and Measurement of Ethnic Identity: Current Status and Future Directions. Journal of Counseling Psychology, 54(3), 271281. http://doi.org/10.1037/0022-0167.54.3.271

Quintana, S. M., \& And Others. (1991). Meta-Analysis of Latino Students’ Adjustment in Higher Education. Hispanic Journal of Behavioral Sciences, 13(2), 155-68.

Rumbaut, R. (2008). Reaping What You Sow: Immigration, Youth, and Reactive Ethnicity. Applied Developmental Science, 12(2), 108-111. http://doi.org/10.1080/10888690801997341 
Sabatier, C. (2008). Ethnic and National Identity among Second-Generation Immigrant Adolescents in France: The Role of Social Context and Family. Journal of Adolescence, 31(2), 185-205. http://doi.org/10.1016/j.adolescence.2007.08.001

Sargent, C. (2012). Special Issue Part I: “Deservingness” and the politics of health care. Social Science \& Medicine, 74(6), 855-857. http://doi.org/10.1016/j.socscimed.2011.10.044

Sears, D. O., Fu, M., Henry, P. J., \& Bui, K. (2003). The Origins and Persistence of Ethnic Identity among the "New Immigrant” Groups. Social Psychology Quarterly, 66(4), 419-437.

Siddiqi, A., Zuberi, D., \& Nguyen, Q. C. (2009). The role of health insurance in explaining immigrant versus non-immigrant disparities in access to health care: comparing the United States to Canada. Social Science \& Medicine (1982), 69(10), 1452-1459. http://doi.org/10.1016/j.socscimed.2009.08.030

Song, M. (2003). Choosing ethnic identity. Cambridge, UK: Polity Press ; Malden, MA.

Stepick, A., \& Stepick, C. D. (2002). Becoming American, Constructing Ethnicity: Immigrant Youth and Civic Engagement. Applied Developmental Science, 6(4), 246-257. http://doi.org/10.1207/S1532480XADS0604_12

Suarez - Orozco, C., Bang, H. J., \& Kim, H. Y. (2011). I Felt Like My Heart Was Staying behind: Psychological Implications of Family Separations \& Reunifications for Immigrant Youth. Journal of Adolescent Research, 26(2), 222-257. http://doi.org/10.1177/0743558410376830

Suarez - Orozco, C., Yoshikawa, H., Teranishi, R. T., \& Suarez - Orozco, M. M. (2012). Growing up in the Shadows: The Developmental Implications of Unauthorized Status. Harvard Educational Review, 81(3), 438-473.

Waters, M \& Pineau, M (2015) The Integration of Immigrants into American Society. Washington, D.C.: National Academies Press. Retrieved from http://www.nap.edu/catalog/21746

Tovar, J., \& Feliciano, C. (2009). “Not Mexican-American, but Mexican”: Shifting ethnic self-identifications among children of Mexican immigrants. Latino Studies, 7(2), 197221. http://doi.org/10.1057/lst.2009.18

Umana-Taylor, A. J., Vargas-Chanes, D., Garcia, C. D., \& Gonzales-Backen, M. (2008). A Longitudinal Examination of Latino Adolescents' Ethnic Identity, Coping with Discrimination, and Self-Esteem. Journal of Early Adolescence, 28(1), 16-50. http://doi.org/10.1177/0272431607308666

Umaña-Taylor, A. J., \& Updegraff, K. A. (2007). Latino adolescents’ mental health: Exploring the interrelations among discrimination, ethnic identity, cultural orientation, self-esteem, and depressive symptoms. Journal of Adolescence, 30(4), 549-567. http://doi.org/10.1016/j.adolescence.2006.08.002

Viladrich, A. (2012). Beyond welfare reform: Reframing undocumented immigrants' entitlement to health care in the United States, a critical review. Social Science \& Medicine, 74(6), 822-829. http://doi.org/10.1016/j.socscimed.2011.05.050

Warin, P. (2007). L'accès aux droits sociaux. Saint-Martin-d'Hères: Presses Universitaires de Grenoble.

Warin Philippe. (2014). L’action sur le non-recours devant des résistances du travail social. Revue Française Des Affaires Sociales, (1), 64.

Waters, M. C. (1990). Ethnic options: choosing identities in America. Berkeley: University of California Press.

Yip, T., Gee, G. C., \& Takeuchi, D. T. (2008). Racial Discrimination and Psychological Distress: The Impact of Ethnic Identity and Age among Immigrant and United States- 
Born Asian Adults. Developmental Psychology, 44(3), 787-800.

http://doi.org/10.1037/0012-1649.44.3.787

Yoshikawa, H. (2011). Immigrants raising citizens: undocumented parents and their young children. New York: Russell Sage Foundation. Retrieved from http://nrs.harvard.edu/urn-3:hul.ebookbatch.PMUSE_batch:muse9781610447072 